David Benhamú Jiménez

Spanish State Open University

Madrid
UDC 811.411.16(460)

DOI https://doi.org/10.18485/fid.2017.7.ch26

\title{
HAKETIA AS THE CURRENT ETHNOLECT IN EDUCATION IN THE WESTERN JUDEO-SPANISH COMMUNITIES OF SPAIN. THE EXAMPLE OF THE JEWISH COMMUNITY OF MELILLA
}

У овом раду, циљ ми је да докажем присуство хакетије у главним сефардским јеврејским заједницама у Шпанији, као и да анализирам тренутни статус овог језика у образовном оквиру тих јеврејских заједница. Део усменог и писаног текста добијеног у теренским истраживањима спровођеним током 2014. и 2015. године, биће размотрен, фокусирајући се на јеврејску заједницу у Мелиљи. Главни циљ је да поделимо са научном заједницом вредност хакетије као етнолекта, као лингвистичког стуба у образовању и његову везу са изумирањем језика.

Кључне речи: хакетија, jaquetia, Мелиља, образовање, јеврејско-шпански.

\section{Introduction}

Nowadays, any researcher and most of the Academic studies on Haketia consider it a dead element, though in Israel some Judeo-Spanish experts are currently speaking of a cultural revival of the language. I may agree that depending on a diverse range of indicators the language is dead, dying or about to die in any of the countries where it is still spoken or partially spoken. However, after the previous statement, I would like to focus on the Haketia or the Haketia incursions that are linguistically alive and found in the spontaneous Spanish of the Western Sephardic Jews of Spain, centering on the JCOM being, in my view, the most representative example of Spain regarding the presence of Haketia.

In fact, there is no cultural revival of Haketia in Spain at all, and among the speakers any trace of its presence is not the result of a linguistic revival policy on the part of the government or of the Jewish communities themselves.

After the presence of Haketia is proved in the Jewish communities of Spain and the situation with the JCOM is analyzed, I will relate the pres- 
ence of Western Judeo-Spanish to the current Jewish education in Spain. The daily Jewish schools of the country have unintentionally contributed since their foundation and together with other crucial factors have decreased the speed at which Haketia is becoming extinct.

\section{Introduction to the sociolinguistics of contemporary Haketia}

In any paper or act, academic or not, carried out in Israel or in Spain regarding Haketia or Sephardic Jews, the Jewish communities of Spain are unknown or rarely mentioned from a synchronic point of view. This statement is firmer when referring to the Spanish Jewish communities located up to our times on the Northern Coast of Africa, the Jewish community of Ceuta and the JCOM and not to mention the analysis of their speech.

An important number of Western Sephardic Jews have started to "come back" to Spain since the end of the $19^{\text {th }}$ Century and during the $20^{\text {th }}$ Century. Those communities brought from Morocco to Spain their traditions including their speech particularities; their nearly extinct Haketia. It is appropriate in this context to talk of the re-hispanization of te Jewish life in all senses, including the decline of Haketia due to its new contact with Spanish. This decline has been stronger in communities like Madrid, Barcelona and Malaga, with a negligible rate of Jews compared to the nonJewish population $(<0.1 \%)$ which diminishes the contact opportunities on a daily basis with other Jews of the same kind and therefore, the natural tendency of those Jews to express themselves with their equivalents as they learnt since they were born.

Mrs. PTB claims in Spanish: “A mí me gusta que mi hihoqu'anacio y s'acriao en Madrid sepa hablah como los nuestroh, tú ya sabehnoh lo mihmo, pero..." (I like that my son that was born and raised in Madrid knows how to speak like us, you know, it is not the same, but...). The informant explained that when "the Jewish friends of her son come to play at their home she is able to hear among some children the use of random words and expressions in "our way of speaking".

This presence is more frequent in the Jewish communities of Gibraltar, Melilla and Ceuta. It can be explained by the constant contact of the Jewish members of those communities. The rest is the result of the 
sizes and isolation of the three cities, their strong traditional and cultural Sephardic values and the higher rate of Jewish presence compared to the non-Jewish residents of each of the cities (between $1 \%-2 \%$ of the population for each of the three cities). Mrs. RBB comments that "una se rejlea a la Avenida y hay un hebreo. Allí donde vaya una ve uno de los nuestros, un /lludío/ (Myself when I go to the "Avenida" there is a Jew. Wherever I go there is one of ours)".

\section{The case of Melilla}

1. Arrival of Haketia in the city

2. The presence of the language in the JCOM

\section{Arrival of Haketia in the city}

The random presence of Jews in the area of Melilla is not relevant for this article before the $19^{\text {th }}$ Century, for the fact that the Haketia arrived in Melilla 150 years ago mainly from Tetouan when those Sephardic Jews were looking for new trade opportunities and with further later Jewish immigrations from the Northwest of Morocco as we will briefly describe in the following paragraph.

Illustration: Registry of population compiled by Salafranca Ortega, Jesús, La población judía de Melilla (1874-1936). Caracas: Asociación Israelita de Venezuela, 1990. P. 72-73.

Jewish newcomers were mainly males of a high socio-economical and cultural status who left behind their families to establish themselves in a recently founded city with economical potential, business opportunities and government incentives but with an important lack of services for their wives and children who arrived in Melilla some years later. Those newcomers were believed to express themselves and to write in the best Spanish. Nevertheless, Dr. Salafranca Ortega in his quoted work of 1990 was able to notice that those Jews knew Haketia and used it in their intimacy or as a secret language with other members of the JCOM. It seems unbelievable, because it is known that Haketia was the language of the lower classes, "la lengua de lospobres, de losincultos, el español mal hablado,... 
(the language of the uneducated, of the poor, the incorrect Spanish), that in the second half of the $20^{\text {th }}$ Century began to be analyzed slightly by the Academics".

The mentioned speakers asked their children not to use Haketia as parents in general encourage theirs not to swear for example. Nevertheless, as children learn to swear in all languages Haketia was passing down the generations. In this group, as stated, with a high standard education in Spanish, Haketia did not appear already as a complete language but in alternation with Spanish, and with the diglossia predominating at the lexical level.

After some decades, an additional more numerous Jewish immigration from Tetouan arrived in Melilla, including on this occasion, Jews of a lower socio-economic status who tended to use Haketia more often and in a more complete manner that the former mentioned group. Those Jews spontaneously contributed to reinforce and to regain some uses of Haketia that the initial immigrants did not count with or had lost. The Jews of the city did not really mix with, marry or attend events of other Jews of a different socio-economical status. There were no rules about Jewish segregation, but they just mixed in limited aspects of their Jewish life. However, the transfer of Haketia between the groups happened because of the frequent Jewish contact in the city. It is necessary to take into consideration that Melilla is a reduced $\left(12.5 \mathrm{~km}^{2}\right)$ and isolated city relatively far from mainland Spain or other nearby Jewish communities, and this brought all the Jews of the city together in some major contexts, narrowing the scope of their social networks: the Synagogue, Jewish employees of Jewish wealthier employers, dense street contact, etc.

An additional but lesser immigration of Western Sephardic Jews of diverse background from Tangier to Oran who knew Haketia or Judezmo also arrived in Melilla. The informant Mrs. VBC says she was born in Tangier and that arrived in Melilla in 1967. She was one of the daughters of the resident Pharmacist. In her interview, after analyzing the large and active Haketia lexicon of her daily speech, Mrs. VBC was asked to further think of words or expressions that she could remember but that are no longer or that were never used at all with the other members of the JCOM. Mrs. VBC insisted in remarking that the use of Haketia in her childhood 
was forbidden and reduced by her parents. However "I knew, we all knew Haketia from the street, the playground of the school, my friends and I used it, also my sisters, my parents used it to speak secretly in front of us as if we did not know, ...Then, I arrived in Melilla and everyone was using it, so I became more fluent, more active, I learnt new words that I use now. Pero una cozza, mi Haketiaes de la wena de la de verdad, y no como ezzajarabullina que adreanen Melilla, y que vamos hazzer" (Just something, my Haketia is the good and the real one, and not like this melted pot that they speak in Melilla, but what can we do?). Two of the sons of this informant were recorded immediately afterwards in a separate room, understanding, recognising and being able to reply to nearly all the questions asked of their mother (ages of the sons; 40 female and 37 male). Besides, they both admitted that they unconsciously continue to use this way of speaking among their relatives and friends and even with their children or as a code language in front of strangers.

As a part of the Jewish history of the city affecting Haketia, I will comment on the last important Jewish immigration, the toshabim that arrived in Melilla from nearby villages escaping from Morocco and that had to be rescued by the JCOM. Their conditions were deplorable with absolutely no education, income or knowledge of Spanish. They brought with them their Judeo-Arabic, their Dariyah and their Tamazight that shaped and twisted the Haketia of the JCOM, together with the Spanish of our days.

2. The presence of the language in the JCOM

Our informant, Mrs. VBC, was referring with her statement and without realising to the main particularity of the Haketia of Melilla or Eastern Haketia, its diversity. Let's underline the three points of her statement:

1. I learnt new words in Melilla that I use now

2. Mi Haketia es de la wena de la de verdad, y no como ezajarabullina que adrean en Melilla

3. Y que vamos hazzer

It took years to get over the natural separation among the different Jews of the city, but they were Jews and this element increasingly brought the entire community together. Although in 2015 there are still significant 
economic and cultural differences the community members see themselves as a whole, without in fact caring about their origins.

As conclusion of our first section of the article, let's review the rest of the statements of the above-mentioned informant: we understand now that new words were brought into the JCOM by the toshabim; those are the new words that she learnt. It was not Haketia, but the community did not know it or did not care if it was or not. Or perhaps, the Sephardic Jews recognised in the speech of the toshabim the Hebrew component of JudeoArabic, and associated it to the Hebrew base of the Haketia, believing that it could probably be another type of Haketia that was finally incorporated in their daily speech. In addition, Mrs. VBC believes her Haketia to be the original, the real one, and she was right, Haketia came from the Northwest of Morocco, Tetouan, Tangier, etc. and therefore, the variety of Melilla sounded to her artificial, not real. With her last sentence (Y que vamos hazzer), she faced the reality and regarded the community in January 2015 as a whole as previously stated, with differences but united. Those ideas are shared by the rest of the JCOM. Mr. EBB, adds to the previous informant that "hay los que tienen flus y los que no tienen, pero que las diferencias del pasado se acabaron porque todos son judíos, ... los matrimonios se basan en el amor, y ya no en la clase social, nos invitamos todos a las bodas (There are those with money and those without money but the differences of the past disappeared because we are all Jews... Marriages are based on love and not anymore on the social classes; we all invite each other to our weddings)".

\section{The Haketia of our days: approaching the JCOM}

Having described briefly how Haketia arrived in Melilla we can turn to an explanation of how it spread to and came to be spoken by the other Jewish communities of Spain, an amalgam mainly of Western Sephardic Jews. These communities continued to grow, especially during the Independence of Morocco in 1956, and settled, in addition to Ceuta and Melilla, in Gibraltar, Seville, Malaga, Barcelona and Madrid. Many of these Jews emigrated in significant numbers to other countries apart from Spain and only around 40,000 "came back" to their Sefarad. These communities 
copied the organization and the operation model of their Sephardic communities in Morocco in which contact among the members was the most solid mainstay of their existence. As a result Haketia inadvertently continued to pass in Spain down the generations, at home, with Jewish friends, at the school and at the tefila. It is important to remark again that the presence of Haketia, as we mentioned above, was more frequent in the Spanish Jewish communities with a larger percentage of Jews in the population and with closed contacts among the members of their own communities, such as Gibraltar, Melilla or Ceuta.

Haketia exists and has remained in those communities as an oral jargon in the spontaneous speech of informal contexts until our days. However, in the last decades new social networks have also induced the speakers to write down the language. This phenomenon may differ from Haketia's traditional or uniformed transcription systems of the Universities. Nevertheless, it seems the only possible alternative to achieve the spontaneous written reminders of Haketia in Spain, taking additionally into account that the Jewish emigration into Spain has fallen off since the foundation of the State of Israel and has become more pronounced over the last decade due to the economic crisis that deeply affected Spain. This means that not only is the language dying but that the Jewish communities of Spain are declining in numbers which consequently affects in the same way the extinction of Haketia in the city of Melilla.

Let's examine the example or Mr. SBB (Speaker A)

A: He comprao 4 en $30 €$

B:¿Dónde lahcomprah y en cuánto lahvendeh?

A: Me lah trae un sajenke las jaftea de Primor las muestras

In English:

A: I have bought 4 for $30 €$

$\mathrm{B}:$ ¿Where have you bought them and what are the selling prices?

B: A sajen brought them to me from Primor where he jaftea-s them, they are samples

The informants when writing Haketia do not follow any rule or consideration of the quoted writing systems or standardizations. They simply adapt the spelling to their linguistic systems, as happens in other languages; in this case Spanish, but it could be French, Hebrew or Spanish from a different area or country. 
1. In Spain, sagen and sajen are written nearly equally with a slightly predominance of sagen vs. sajen, as in Spain ge/je are the same sound.

2. Jaftea (inf. jaftear), may be seen in the Haketia speakers of Spain with " $h$ ", haftear or with " $j$ ". It is an aspirated " $h$ " that younger generations are turning it into a " $\mathrm{j}$ " due to the influence of Spanish. Almost all of the informants over 37 years old used " $h$ " when writing instead of " $\mathrm{j}$ " and the opposite for the informants under the age of 37. Anyway, in this last group in which " $\mathrm{j}$ " is more frequent, there is a considerable use of " $h$ " (34\%), which in my view shows that even in younger generations the shift is not yet deeply rooted or that it may remain as it is.

An interview and a follow-up questionnaire based on the interviews were carried out among members of different profiles over a period of 6 months in the above-mentioned Spanish Jewish communities. Due to space limitation and as we have already reviewed some comments of the interviews, a sample questionnaire will conclude the second section of the article, intending to provide an additional proof of the current presence of Haketia in Spain through the JCOM. Supplementary aspects of the research such as the interviews and the questionnaire justification and structure, etymology, use, particularities of each of the entries and other relevant facts will predictably be commented on in the thesis.

\section{The questionnaires}

The questionnaires has 18 questions and combines linguistic and cultural issues in Spanish or in Haketia about the Haketia of the members, their community, their perspective of the future, etc.. It was slightly adapted to each of the communities. A total of 652 potential speakers or relatives of speakers of Haketia in Spain and Israel replied to the questionnaire of which 225 were informants either from Melilla or originating from the city. With random exceptions most of the answers were the same or quite similar across all the informants, chiefly when they were from the same city.

In January 2015, one of the questionnaires was completed by Mrs. EBB, 28, born in Melilla in 1985, married, mother to two children of 5 and 2 years old. She works as an economist. Current place of residence: Melilla. Previous oral interview recorded in July 2014. 


\begin{tabular}{|c|c|c|c|}
\hline \# & Question & no. & no. $(\%)$ \\
\hline \multirow[t]{6}{*}{1} & $\begin{array}{l}\text { Elija de entre las siguientes, la afirmación que } \\
\text { más se adecue con su perfil: }\end{array}$ & 1 & $100 \%$ \\
\hline & Soy judío/a residente en Melilla & 1 & $100 \%$ \\
\hline & Soy judío/a melillense no residente en Melilla & 0 & $0 \%$ \\
\hline & $\begin{array}{l}\text { Mi padre/madre o abuelo/a o cónyugue/pareja es o } \\
\text { ha sido judío/a melillense }\end{array}$ & 0 & $0 \%$ \\
\hline & Me relaciono de vez en cuando con judíos/as melillenses & 0 & $0 \%$ \\
\hline & No me identifico con ninguna de las opciones anteriores & 0 & $0 \%$ \\
\hline
\end{tabular}

Translation: Choose among the following statements the closest to your profile (I am a Jew living in Melilla, I am a Jew born in Melilla not living currently in the city, I am a relative or I am connected somehow to a Jew of Melilla, I meet sometimes with Jews from Melilla, No one of the above matches me).

Comments: In this case, the informant confirms that she is Jew, that she was born in Melilla and that currently she lives in the city.

\begin{tabular}{|c|c|c|c|}
\hline \# & Question & no. & no. $(\%)$ \\
\hline \multirow[t]{3}{*}{2} & $\begin{array}{l}\text { ¿Considera que además del español existe hoy en } \\
\text { día un habla/jerga particular de la comunidad judía } \\
\text { de Melilla? Ejemplo: } \underline{\text { Rajleapa' que no nos sofee el }} \\
\text { sajen }\end{array}$ & 1 & $100 \%$ \\
\hline & $\begin{array}{l}\text { Sí. Sí que hay un habla/jerga particular de esta } \\
\text { comunidad }\end{array}$ & 1 & $100 \%$ \\
\hline & $\begin{array}{l}\text { No. No reconozco ningún habla/jerga particular en esta } \\
\text { comunidad }\end{array}$ & 0 & $0 \%$ \\
\hline
\end{tabular}

Translation: Besides Spanish, do you consider that there is an existing particular language/jargon in the JCOM? Example: Rajlea pa' que no nossofee el sajen (sentence in Haketia meaning: Move so that the other/the non-Jew does not look at us).

Comments: In this case as in $98 \%$ of the questionnaires and in the $100 \%$ of the answers of the informants of Melilla, a presence of a particular speech in the community is confirmed. It needs to be remarked that the term Haketia was never used on the questionnaires so as not to influence the informants on whether they speak Haketia or not. 


\begin{tabular}{|c|l|c|c|}
\hline$\#$ & \multicolumn{1}{|c|}{ Question } & no. & no. (\%) \\
\hline 3 & $\begin{array}{l}\text { Las formas «parabien», «mejorado a los 120»y «no } \\
\text { sea tu falta mi weno» son propias de los hebreos o le } \\
\text { parece que las dicen también los sajenis? }\end{array}$ & $\mathbf{1}$ & $\mathbf{1 0 0 \%}$ \\
\hline & Las dicen solo los hebreos & $\mathbf{1}$ & $\mathbf{1 0 0 \%}$ \\
\hline & Las dicen los hebreos y también los sajenis & 0 & $0 \%$ \\
\hline
\end{tabular}

Translation: Are the mentioned expressions used by the Jews of your community or are they used as well by the rest of the non-Jewish speakers of the city?

Comments: Absolutely in all the questionnaires the informants confirmed that only the Jews of their respective cities were using those expressions.

\begin{tabular}{|l|l|c|c|}
\hline$\#$ & \multicolumn{1}{|c|}{ Question } & no. & no. $(\mathbf{\%})$ \\
\hline $\mathbf{4}$ & $\begin{array}{l}\mid \\
\text { ¿Dónde aprendió las expresiones anteriores? }\end{array}$ & $\mathbf{1}$ & $\mathbf{1 0 0 \%}$ \\
\hline $\begin{array}{l}\text { De oída en casa y/o en el Talmud Torah y/o con los } \\
\text { amigos, cónyuge y/o vecinos judíos }\end{array}$ & $\mathbf{1}$ & $\mathbf{1 0 0 \%}$ \\
\hline \begin{tabular}{l} 
En un instituto o academia \\
\hline No las he aprendido en ningún sitio
\end{tabular} & 0 & $0 \%$ \\
\hline
\end{tabular}

Translation: Where did you learn the aforementioned expressions?

Comments: Once again absolutely all the informants confirmed that at home, at the Jewish school, with their partners and with Jewish neighbours. It is remarkable that the Jewish school has and continues to be one of the key institutions that are sustaining Haketia up to our days in the Spanish Jewish communities as we will discuss in the last section of this article. I would like to underline that none of the informants chose the last option "I have never learnt them anywhere".

\begin{tabular}{|c|c|c|}
\hline$\#$ & Question & \multicolumn{1}{c|}{ Text } \\
\hline $\mathbf{5}$ & $\begin{array}{c}\text { Escriba ¿qué significa? «ES UN JIAL PERO } \\
\text { EL MESQUÍN ESTÁ } D A R B E A D O »\end{array}$ & - Es guapo pero el pobre está \\
& loco & \\
\hline
\end{tabular}

Translation from Haketia: Write the meaning for: «ES UN JIAL PERO EL MESQUÍN ESTÁ DARBEADO» (Meaning in English: he is handsome but poor of him, he is crazy). 
Comments: In this question my aim was to achieve a direct translation from Haketia into Spanish from a common daily life example. Ninety percent of the informants had a correct answer, 97\% being the rate for the JCOM. The remaining percentage of informants did not leave the box blank but made some minor mistake or confused the words with similar words or used a Haketia false friend word.

\begin{tabular}{|c|l|c|c|}
\hline$\#$ & \multicolumn{1}{|c|}{ Question } & no. & no. (\%) \\
\hline $\mathbf{6}$ & $\begin{array}{l}\text { ¿Le gustaría que esta forma particular de hablar/ } \\
\text { jerga se quede entre nosotros o que la sepan también } \\
\text { los goyim? }\end{array}$ & $\mathbf{1}$ & $\mathbf{1 0 0 \%}$ \\
\hline $\begin{array}{l}\text { Que se quede solo entre nosotros } \\
\text { Que la conozcan los goyim también } \\
\text { Me da igual, no tiene importancia }\end{array}$ & $\mathbf{1}$ & $\mathbf{1 0 0 \%}$ \\
\hline
\end{tabular}

Translation: Would you like this jargon of our community to remain within your community or would you like it to be known by the non-Jews?

Comments: $97 \%$ of the informants decided to keep this way of expression within the community and the percentage rose to $99 \%$ within the JCOM. It was surprising that some of the few Melilla Jewish promoters of Sephardism and Haketia that publically admitted their interest in raising the awareness of Jews, Ladino and Haketia among the general population of Melilla, privately opposed divulging to non-Jews any information regarding this particular way of speaking of their community.

\begin{tabular}{|c|c|c|}
\hline$\#$ & Question & Text \\
\hline 7 & Escriba en nuestra habla/jerga: «MIRA & - Shofea como maklea el arian \\
\hline & CÓMO COME EL MUERTO DE HAMBRE» & \\
\hline
\end{tabular}

Translation: Write in our jargon: «MIRA CÓMO COME EL MUERTO DE HAMBRE»(Meaning in English: Look how this stingy eats).

Comments: In this question my intention was to achieve a reverse translation from Spanish into Haketia which as in other languages tends to be more difficult for the speakers, and especially in dying languages. In this case, the ranking of correct answers remained as follows: $94 \%$ for Melilla, $89 \%$ for Seville, $88 \%$ for Ceuta, $65 \%$ for Madrid, $58 \%$ for Malaga 
and $52 \%$ for Gibraltar. Once again, only answers with no mistakes at all were taken into account. Among the incorrect answers, there was an important percentage in each of the communities in which the result was approximate or just some words were missing. If those nearly correct replies were counted the ranking of correct answers would increase.

\begin{tabular}{|l|l|c|c|c|}
\hline$\#$ & \multicolumn{1}{|c|}{ Question } & no. & no. (\%) & promedio. \\
\hline $\mathbf{8}$ & $\begin{array}{l}\text { iCon qué frecuencia suele utilizar o escuchar } \\
\text { esta habla/jerga? Completa todas las opciones } \\
\text { (0 - nunca, 1- casi nunca, 2 - solo a veces, 3 - es } \\
\text { lo habitual, 4 - casi siempre, 5 - siempre) }\end{array}$ & $\mathbf{1}$ & $\mathbf{1 0 0 \%}$ & $\mathbf{3 . 3 3}$ \\
\hline & & & \\
\hline En casa con mi familia cercana & 1 & $100 \%$ & 5 \\
\hline Con la gente de la comunidad & 1 & $100 \%$ & 5 \\
\hline Para que un sajen no sofee lo que adreamos & 1 & $100 \%$ & 3 \\
\hline Para estajear aunque sea de ajsifos & 1 & $100 \%$ & 0 \\
\hline En nuestros comercios, mundo laboral, etc. & 1 & $100 \%$ & 2 \\
\hline $\begin{array}{l}\text { Como elemento de humor y cariño entre nosotros } \\
\text { o para referirnos a ajenos al grupo }\end{array}$ & 1 & $100 \%$ & 5 \\
\hline
\end{tabular}

Translation: Which are the frequencies and uses of the language that you identify in your community (Range from 0 - never, to 5 - always: At home with my family, with other members of the community, so that the non-Jews do not understand us, for joking even not real joking, in our shops or working atmosphere, as an element of humour or love among us to refer to other people).

Comments: Most common uses are to communicate within the members of the community in any informal situation, in our homes, etc. The responses remained relatively similar regarding uses and in the ranking positions, particularly when the informants belonged to the same city.

\begin{tabular}{|c|r|r}
\hline$\#$ & Question & Text \\
\hline 9 & ¿A qué me refiero si digo que: la vecina del primero es & - Lesbiana \\
& $\ll M A K O D A » ?$ & \\
\hline
\end{tabular}

Translation: What do we mean if I comment that the girl living on the first floor is «MAKODA» (lesbian)?

Comments: This question was intended to reflect regional differences in Haketia. In this case, $M A K O D A$ is a certain type of yellow omelette 
with carrots, peas and eggs. But in some areas like Melilla, it acquired a new meaning: lesbian. In Spanish tortillera is a vulgar term meaning lesbian that was adopted from this language to Haketia as a semantic calque changing its grammatical category (tortillera $>$ makodera $>$ makoda). The word and both of its meanings were recognised by $97 \%$ of the interviewed members of the JCOM.
\#
Question
10 En el caso de que sus padres o sus abuelos fueran nacidos en Marruecos y no en Melilla, indique en qué ciudad o zona de Marruecos nacieron y si sabían español antes de llegar a Melilla

Text

Translation: In case your parents were born in Morocco and not in Melilla, indicate what city or area they came from and if they spoke Spanish before they arrived in Melilla.

Comments: This question was intended to reflect from where Haketia, Dariyah, Tamazight or Judeo-Arabic originated. In this case, the question was not answered for an unknown reason. However, comparing it with the previous oral interview to the informant we could clarify that the grandparents came from Tetouan, so that the Haketia should be predominant to the other referred languages. Conversely, the informant was able to recognise the expressions used in the other languages. It confirms the linguistic transfers among the Jews of the JCOM which resulted in a pan-Haketia comprehensible mainly to their own community. This panHaketia continues at the same time to perform new uses, to emigrate with its speakers out of Melilla and to become extinct.

\begin{tabular}{|c|c|c|}
\hline$\#$ & Question & \multicolumn{2}{c|}{ Text } \\
\hline 11 & $\begin{array}{c}\text { Indique en qué calle o barrio de Melilla vivía usted } \\
\text { cuando era un niño/a o deje la pregunta en blanco si } \\
\text { no vivió en Melilla }\end{array}$ & $\begin{array}{c}\text { - Calle marina - } \\
\text { centro }\end{array}$ \\
\hline
\end{tabular}

Translation: Indicate which street or neighbourhoods of Melilla you lived in, in your childhood or leave the reply in blank if you were not living in the city during that time.

Comments: This question intends to reflect whether the Haketia/ Dariyah/Judeo-Arabic/Tamazight was reinforced in childhood or not. This 
can be easily determined by knowing if they were raised in the traditional Jewish neighbourhoods of the city with a larger amount of speakers of any of those languages and where the contact among Jews was obviously more frequent. This factor offers crucial details to understand the linguistics habits of each of the speakers of the JCOM and their preference to use certain words/expressions above another. Our informant, Mrs. EBB, used to live in an area inhabited mainly by Catholics where Haketia was not for the most part widely spread. This confirms the assumption that the language was learnt at home with family or friends, or in the playground of the school, but exclusively in a Jewish context.

\begin{tabular}{|c|c|c|c|}
\hline \# & Question & no. & no. $(\%)$ \\
\hline \multirow[t]{4}{*}{12} & $\begin{array}{l}\text { ¿Estudió en el Talmud Tora / Hispano israelita / } \\
\text { Liceo? }\end{array}$ & 1 & $100 \%$ \\
\hline & Sí & 1 & $100 \%$ \\
\hline & No, estudié en Melilla pero en otro colegio no judío & 0 & $0 \%$ \\
\hline & No es aplicable cuando era pequeño/a no vivía en Melilla & 0 & $0 \%$ \\
\hline
\end{tabular}

Translation: Did you study in the Talmud Tora/Hispano israelita/Liceo? (Yes, No I did study in Melilla but in a non-Jewish school, I did not live in Melilla when I was in school).

Comments: This question is equally important for the last section of our article as it shows how the daily primary school may determine the transmission of Haketia in the current Spanish Sephardic communities from generation to generation together with family and friends. In the JCOM, as in the other communities, the presence of Haketia was slightly lower in informants that did not attend daily Jewish schools, and also in those cities with no daily Jewish schools Haketia in general terms was also found to be less present or weaker.

\begin{tabular}{|c|c|c|}
\hline$\#$ & Question & Text \\
\hline $\mathbf{1 3}$ & ¿Cómo se dice la palabra «SÓTE» en femenino; para una & - Sotia \\
\hline & mujer? Esta tía es una ... & \\
\hline
\end{tabular}

Translation: How do you form the feminine of the word SÓTE (Word in Haketia meaning stupid) 
Comments: In this question I am again looking for particular characteristics of the Haketia of the JCOM. In the standard Haketia the feminine would be SOTÁ, but in the JCOM it is SOTÍA in 98\% of cases, and SOTÁ in the remaining $2 \%$. In the oral interviews, $39 \%$ of the JCOM speakers would recognise SOTÍO as an alternative form for the masculine SÓTE created from the feminine form SOTÍA.

\begin{tabular}{|c|c|c|}
\hline$\#$ & Question & Text \\
\hline $\mathbf{1 4}$ & ¿Qué significa «EL ESTAARRÁS SE & - EI pesado se está espabilando \\
\hline & ESTÁ JAIREANDO $?$ ? & \\
\hline
\end{tabular}

Translation: What does the sentence "EL ESTAARRÁS SE ESTÁ JAIREANDO" mean (Sentence in Haketia meaning "the annoying/tiresome is fidgety").

Comments: In this question I am again looking for particular features of the Haketia of the JCOM but with a longer sentence than in the previous example to be able to determine if at this stage of language vitality, the speakers can still deal with sentences or just with isolated words/ expressions.

\begin{tabular}{|l|l|c|c|}
\hline$\#$ & \multicolumn{1}{|c|}{ Question } & no. & no. (\%) \\
\hline 16 & $\begin{array}{l}\text { ¿Piensa que la Comunidad judía de Melilla en un } \\
\text { momento dado acabará marchándose por completo } \\
\text { a la península, Israel u otro país por diferentes } \\
\text { motivos? }\end{array}$ & $\mathbf{1}$ & $\mathbf{1 0 0 \%}$ \\
\hline $\begin{array}{l}\text { Sí, desaparecerá algún día } \\
\text { No, puede que disminuya pero no desaparecerá }\end{array}$ & $\mathbf{1}$ & $\mathbf{1 0 0 \%}$ \\
\hline
\end{tabular}

Translation: Do you think that the community of Melilla will ever disappear or emigrate to any city in the mainland of Spain, Israel or another country?

Comments: This question received a less unified reply among the informants (46\% YES - 54\% NO). Since the JCOM have being emigrating from their city for years the informants differ in this question depending on their age, socio-economic status, religious observance, if they have family that did Aliah in the past, profession and employment status, etc. 


\begin{tabular}{|c|c|c|}
\hline$\#$ & Question & Text \\
\hline $\mathbf{1 7}$ & Escriba su nombre completo y si desea & - EXXXXBXXXXXX \\
& mantener el anonimato solo sus iniciales. & BXXXXXX. La vainafá \\
En mi caso, mis iniciales son DBJ de & \\
David Benhamú Jiménez & \\
\hline
\end{tabular}

Translation: Write your full name or your initials.

Comments: Most of the informants decided to use only their initials. Only $48 \%$ of the informants of the JCOM decided to make a reference to their nicknames, although those are well known by the rest of the members of the community. In Madrid 79\% of the informants agreed to provide their nicknames or the nicknames of their parents or grandparents which often are adopted or partially adopted by the new generations.

\begin{tabular}{|c|c|c|}
\hline$\#$ & Question & \multicolumn{2}{c|}{ Text } \\
\hline $\mathbf{1 8}$ & $\begin{array}{c}\text { Si la conoce o le apetece me gustaría que me } \\
\text { comentase alguna anécdota graciosa o interesante } \\
\text { antigua de la comunidad judía de Melilla, o de sus } \\
\text { padres o abuelos o el apodo familiar que tiene usted } \\
\text { en la comunidad. }\end{array}$ & $\begin{array}{c}\text { he } \\
\text { respondiendo }\end{array}$ \\
\hline
\end{tabular}

Translation: Tell any old funny or interesting anecdote of the JCOM, of your parents, of your grandparents or comment on the nickname of your grandparents.

Comments: In this question the replies were diverse. Many informants left it in blank (69\% in the JCOM and 48\% in Madrid). Other informants on their own decided as in this case, to connect their anecdote to Haketia (39\% of the answers in the JCOM). Our informant finishes the questioner joking in Haketia (Me he jaireado respondiendo - In English, I have got excited answering the questionnaire).

\section{Haketia in Politics and Education in Spain}

Having established the presence of Haketia in the Western Sephardic communities of Spain, the current status of Haketia in Politics and Education in the Spanish Jewish communities and in Spain itself will briefly be presented. 
Regarding politics it is necessary to mention the New Sephardic law. However, it has not yet being fully defined whether the Spanish or the Haketia of the Western Sephardic Jews will be measured, or both of them and which parameters will be employed. Maybe the mention of Haketiain the law simply remains as a commemoration of the traditional Jewish languages, Haketia and Judezmo/Ladino.

Besides, the recently mentioned approved law, I have been able just to find some references to the current framework of Haketia in Spain.

1. Declaration for a pact of interculturality in the city of Melilla of 21.07.2014

2. Isolated press releases of HM the Government of Gibraltar, where they do not mention Haketia specifically, but the linguistic Jewish heritage of their city, cultural being and the Llanito.

During the XV International Conference on Minority languages held in Belgrade, Serbia May 28th - 30th 2015 and due to the lack of international awareness of Haketia, Prof.Jelena Filipovic proposed to officially inform the European commission on regional and minority languages about the existence of Haketia at the European Union for initializing the recognition process of this speech as a language in danger. However, after informing the community which was a prerequisite of the European commission, the own speakers completely opposed to any sort of recognition claiming that the language is part of the intimacy and the heritage of their Jewish culture. Besides, some of the renamed, educated and active members of the JCOM confirmed that they strongly believe that it is not productive to invest resources in promoting a language that is dead, "que es de losmayores" (of the old people) and that the "community has priority in other matters which are the key for the survival of the community". "We do not hate the language, we love it and we feel culturally attached to it and randomly in silence we use it at home, but it must simply be understood that there is no point to it...".

As continuation of the previous paragraph and analysing the field of education, Haketia was not taken into consideration at any of the two daily Jewish schools of Spain: El Ibn Gvirol Estrella Toledano of Madrid and El 
Liceo Sefardi of Melilla. After an interview with each of the heads of the respective schools they confirmed that "Haketia was not of interest for the educative community and it is present exclusively as a valuable cultural background that was sometimes mentioned in the classes and heard in the schools in one way or another among some children, parents and even Jewish teachers".

\section{Haketia as a Cultural Language in Education}

Nowadays a large number of Jewish communities in the galut, as it is in the the case of Spain, are established around a tefila, a Jewish school, a mikve and a Kosher butcher's shop, or at least around any or some of these. Besides, in all of the cases where there is a daily Jewish school those operate as community centres for all the Jewish members beyond school hours. For example, in the case of Melilla, those centres normally host marriages, shiureidat, shabbatot, etc. which encourages the community to increase their contact.

Haketia is being used in the Jewish communities of Spain as is confirmed by the recorded interviews and the informant's answers to the questionnaires, providing proof to the Academic community. On the other hand, as Haketia was not considered in the daily Jewish schools of Spain and in the interviews and in the questionnaires its presence was greater in those cities with a daily Jewish school. Haketia is not the instruction language or a foreign language. However, it is present and it is used as an ethnolect in the playgrounds and in the social activities that take place under the umbrella of the schools on weekdays, at weekends, and during summer and Jewish holidays.

I will now list the 10 Haketia words/expressions that appeared more frequently in the speech of the informants during the field research in the playground and the entrance of each of the two schools during an immersion period of two weeks in June 2014. 


\begin{tabular}{|c|c|c|}
\hline RANKING & MADRID & MELILLA \\
\hline 1 & sagen & sagen \\
\hline 2 & boril & mi rey/mi reina \\
\hline 3 & cocha & adrear \\
\hline 4 & cuajada & sdaaras \\
\hline 5 & mi rey/mi reina & boril \\
\hline 6 & No aian mal & capará \\
\hline 7 & parabien & laister \\
\hline 8 & adrear & wowowo \\
\hline 9 & meerra & rajlear \\
\hline 10 & wo porti & darbear \\
\hline
\end{tabular}

\section{Conclusion}

Haketia in Spain continues every day to die out faster or become more diluted by Spanish. Its usage is declining considerably in the religious and commercial aspects of Jewish life where it used to be popular. It occurred due to the change in the religious command from Tetouanto the Great Rabbinate of Jerusalem and because of the considerable decrease of Jewish traditional businesses and in general of life habits and emigration of the Jewish communities of Spain.

Both schools have a different conception of education and both see Spanish or English as the first instruction languages with English, French or Hebrew as foreign languages. Haketia therefore is by now, the ethnolect that children, parents and Jewish teachers bring to school from their homes. They bring it to the informal contexts of a school that go beyond the learning hours and the school is conceived as a meeting point and cultural centre for the respective communities. The diglossia happens to occur in everyday life and it is easily tangible to anyone approaching those Jewish communities, the homes of most of the members and above all their social life which often takes place in the school facilities. Haketia is a dying variety of Spanish which is present in the Jewish communities of Spain. This presence is predominantly lexical and it appears spontaneously in informal contexts of daily life. The number of speakers is decreasing on account of the Jewish emigration from Spain. However, until our days in some communities like the JCOM the members/informants know at least 50 words/ 
expressions in Haketia and use them with their family and friends. Haketia has passed from generation to generation and it is surprising how it has managed to survive. One of the main preventers of its ultimate demise has been the Jewish education that has unintentionally permitted its dissemination through frequent contact among the members of the community.

\section{References:}

Aki Jerushalayim, Issue: (April1979), Autoridad Nasionala del Ladino, Israel.

Bendayan de Bendelac, Alegría, (1995), Diccionario del judeoespañol de los sefardies del norte de Marruecos, Asociación Israelita de Venezuela, Caracas.

Bentolila, Yaakov, (above to be published), Dictionary of the Hebrew components in Haketia, Israel.

Hassán, Iacob M., (1978), Transcripción normalizada de textos judeoespañoles, Estudios Sefardíes 1.

Kirschen, Bryan (2014), The (Not-So) Distant Relation between Spanish and Arabic, Journal Issue:Voices, 2(1), http://eprints.cdlib.org/uc/ item $/ 6 \mathrm{w} 47 \mathrm{k} 24 \mathrm{~s}$

Moreno, Aviad, (2014), Ethnicity in Motion: Social Networks in the Emigration of Jews from Northern Morocco to Venezuela and Israel, 1860-2010, Beer Sheva, Israel.

Pinto-Abecasis, Nina, (2014),The Peacock, the Ironed and the HalfWomen: nicknames, humor and folklore in the day-to-day speech of Tetuan'sHaketia-speaking Jews. Ben Zvi Institute of Jerusalem, Israel.

Salafranca Ortega, Jesús F., (1990), La población judía de Melilla (18741936), Asociación Israelita de Venezuela, Caracas.

UNESCO Atlas of the World's language in danger, third ed. 2010.

\footnotetext{
Abstract

In this paper, I aim to prove the presence of Haketia among the main Sephardic Jewish communities of Spain as well as to analyze the current status of this language in 
the education framework of those Jewish communities. Part of the oral and written text obtained in field research carried out during 2014 and 2015 will be examined focusing on the Jewish community of the city of Melilla. The main purpose is to share with the scientific community the value of Haketia as ethnolect, as a linguistic pillar in education and its connection to its dying presence.

Keywords: haketia, jaquetia, Melilla, education, judeo-spanish.

\section{Biographical statement}

MR. DAVID BENHAMÚ JIMÉNEZ, PhD Candidate on Jewish Linguistics of UNED, Spanish State Open University - www.uned.es (Madrid, Spain)

Telephone: +972-54-9194666

Address: 16 Assaf St. Apartment 4, 5253129, Ramat Gan, Israel

http://dbenhamujimenez.jimdo.com/ (The website contains information in Spanish and in English about the research program, a CV and a list of the articles, publications, etc.)

E-mail: dbenhamujimenez@outlook.com 